\title{
Wellbeing in the Irish Junior Cycle: The Potential of Religious
}

\section{Education}

\author{
Abstract \\ Wellbeing is central to the new Junior Cycle (lower secondary education) in Ireland as a \\ principle and curricular area. This paper argues that while it should never be the case \\ that the rights of parents or their children regarding Religious Education are \\ compromised, Religious Education can make a real and positive contribution to \\ wellbeing in the Junior Cycle. The paper begins by reviewing two recent international \\ longitudinal studies to demonstrate the strong positive correlation between religion and \\ wellbeing. It goes on to highlight the potential of Religious Education in helping \\ schools to fulfil the Junior Cycle wellbeing requirements. It concludes that as a \\ legitimate source of wellbeing, Religious Education with sound content and pedagogy, \\ well taught by qualified and supported teachers, can be an integral part of a Junior \\ Cycle programme.
}

Keywords: wellbeing, religion, Junior Cycle, Religious Education

\section{Introduction}

Humanity has always been concerned with what it is to be well and live well. The search for wellbeing has been expressed in different ways over time. Socrates deemed that the unexamined life is not worth living. According to Joan of Arc, 'one life is all we have ... to sacrifice what you are and to live without belief, that is a fate more terrible than dying.' For others, it has to do with a sense of perspective: 'I felt sorry for myself because I had no shoes, until I met a man who had no feet' says the Jewish proverb. 
In recent years wellbeing both as concept and lived reality has gained increasing prominence in international education literature (O'Brien, 2008) and in Irish education policy. The Department of Health and the Department of Education and Skills have supported a range of initiatives aimed at promoting health and wellbeing in postprimary schools, such as the Framework for Developing a Health Promoting School Post-Primary (2013), Well-Being in Post-Primary Schools Guidelines for Mental Health Promotion and Suicide Prevention (2013), Responding to Critical Incidents: Guidelines and Resource Materials for Schools (2016), and the Active School Flag (NCCA, 2017, 14). The Wellbeing Policy Statement and Framework for Practice 2018-2023 of the Department of Education and Skills sets out to ensure that by 2023 the promotion of wellbeing will be at the core of every school (Department of Education and Skills (DES), 2018a). It is a concern taken seriously by that Department in its current formulation of a new Junior Cycle (Department of Education and Skills (DES), 2015).

\section{Wellbeing in the new Junior Cycle}

Junior Cycle is the first stage of post-primary (secondary) education in Ireland. A three year programme for students aged 12 to 15 approximately, it has recently been the subject of major reform. The Framework for Junior Cycle (hereafter, Framework) makes provision for wellbeing both as a principle and a curricular subject (National Council for Curriculum and Assessment (NCCA), 2015). The definition of wellbeing for the purposes of this paper is that offered by the Guidelines for Wellbeing (hereafter, Guidelines) (NCCA, 2017a), which accompany the Framework. According to the Guidelines, 'student wellbeing is present when students realise their abilities, take care of their physical wellbeing, can cope with the normal stresses of life, and have a sense of purpose and belonging to a wider community’ (NCCA, 2017a, 17). 
The principle of wellbeing permeates all aspects of a school's Junior Cycle programme. From 2020, schools are obliged to provide a minimum 400 hours of timetabled wellbeing for students over the course of the 3 year programme. The Guidelines expect that schools will build on substantial work they are already doing in support of students' wellbeing in a way that makes the school's culture and ethos and commitment to wellbeing visible to students. They will 'include learning opportunities to enhance the physical, mental, emotional and social wellbeing of students [and] enable students to build life skills and develop a strong sense of connectedness to their school and to their community' (NCCA, 2017a, 8).

According to the Guidelines, the curricular areas of Civic, Social and Political Education (CSPE), Physical Education (PE), Social, Personal and Health Education (SPHE), and guidance-related learning, are the 'main pillars' for building a wellbeing programme, with the possibility of including elements of subjects, including Religious Education (RE) (NCCA, 2017a, 50). This paper argues, with due regard to the rights of parents and students, that RE can be central to wellbeing in Junior Cycle education. As a legitimate source of wellbeing, Religious Education with sound content and pedagogy, well taught by qualified and supported teachers, can be an integral part of the Junior Cycle wellbeing programme. At the same time, it should never be the case that the rights of parents who do not wish their children to study Religious Education are compromised.

The structure of the argument is as follows:

a) Firstly, the paper sets the context for the paradigm shift towards wellbeing in education, with reference to a recent report from one global leader in the field of educational change; 
b) Secondly, the discussion demonstrates the strong positive correlation between religion and wellbeing; 'religion' and 'wellbeing' can be ambiguous terms, holding multiple understandings. Five dominant conceptions of religion and four conceptions of wellbeing prevalent in recent research are explored in a later section. Generally, and for the purposes of this paper, religion is understood as belief in and/or worship of a higher power, especially a personal God or gods.

c) Thirdly, the paper highlights the potential of Religious Education (RE) in helping schools to fulfil the Junior Cycle wellbeing requirements. Religious Education in Junior Cycle includes both 'the religious and non-religious response to human experience' (NCCA, 2019, 4). It is understood as the 'critical encounter' between religion and education:

The use of the word critical indicates that this encounter is intentional and draws on both religious and educational principles to create the possibility of a critically reflective dialogue between the learner and religion(s) for the purpose of understanding both the content and expression of religious beliefs (NCCA, 2017b, 6).

A 'critical encounter' also allows room for students to engage with the adverse influences of religions and how religion can be colonised and politicised as a force for harm as well as good.

Most European states provide Religious Education in publicly funded schools (NCCA, 2017b, 25). Although the approach varies across states, common objectives among most syllabi include:

o to encourage pupils to be sensitive to religion and the religious dimension of life 
$\circ$ to provide orientation among the variety of existing religious traditions and worldviews, including non-religious convictions

○ to provide knowledge and understanding of religious beliefs and experiences (Schreiner, 2013).

The situation of Religious Education in Europe, and the development and current status of post-primary Religious Education in Ireland, are discussed in the final section of this paper.

\section{The paradigm shift in education towards wellbeing: the context from a global leader}

The Canadian province of Ontario is an established global leader in educational change, with widely- acclaimed results on student achievement and equity on international large-scale assessments (Campbell et al, 2017). Only Finland exceeds Canada in terms of equal opportunity along with positive outcomes for low-income students (Parkin, 2015). Over the past 15 years, Ontarian priorities have shifted. In 2018, the Council of Ontario Directors of Education (CODE) published a report articulating a paradigm shift in education, which has implications for many world education systems. The report describes a move from The Age of Achievement and Effort to the Age of Learning, Wellbeing and Identity (CODE, 2018, 4).

\section{The Age of Achievement and Effort}

The report outlines how internationally, educational reform in the Age of Achievement and Effort was driven by four compelling questions

1) How are we doing?

2) How do we know?

3) How can we improve? 
4) How can this benefit everyone?

These questions led educators to an era of performance, measurement and improvement drive. But the focus on performance measures and achievement also brought problems: 'Its data-driven approach led educators to concentrate more on students' deficits than their assets. Teachers felt constrained by policy pressures in a rapidly changing environment' (CODE, 2018, 5).

Compelling questions of achievement and improvement always deserve attention. However, the Age of Learning, Wellbeing and Identity throws up deeper, more profound questions for societies and schools, which cut to the very core of who we are:

1) Who are we?

2) What will become of us?

3) Who will decide?' (CODE, 2018, 5)

The CODE report argues that these questions emerge from several international trends:

\section{A) Mental Health Issues}

First, there is a global epidemic of mental health problems among young people. Ireland is no stranger to this trend. The recent 'My World' National Survey of Youth Mental Health found that almost one in three young people had at some time experienced mental health difficulties (Dooley and Fitzgerald, 2012). The study showed that these difficulties generally emerged in early adolescence and peaked in the late teens and early twenties, during the key transitional period into adulthood.

\section{B) Changing Populations}

Second, migration and 'the greatest refugee crisis in 50 years' is changing traditional demographics. Census 2016 puts Ireland's population at 4,761,865 (Central Statistics Office (CSO), 2017, 8). Over 200 different nationalities live in Ireland with the number 
of Irish residents born outside Ireland at 810,406 (i.e. $17.3 \%$ of the population). Census 2016 also indicates a marked change in religious affiliation as shown in the table below (72).

Table 8.1 Population by religion, 2011 and 2016

\begin{tabular}{|c|c|c|c|}
\hline Religion & 2011 & 2016 & $\begin{array}{r}\text { Percentage } \\
\text { change }\end{array}$ \\
\hline \multicolumn{4}{|c|}{$000 s$} \\
\hline Roman Catholic & $3,861.3$ & $3,729.1$ & -3.4 \\
\hline Church of Ireland & 129.0 & 126.4 & -2.0 \\
\hline Muslim (Islamic) & 49.2 & 63.4 & 28.9 \\
\hline Orthodox & 45.2 & 62.2 & 37.5 \\
\hline Christian & 41.2 & 37.4 & -9.1 \\
\hline Presbyterian & 24.6 & 24.2 & -1.6 \\
\hline Hindu & 10.7 & 14.3 & 34.1 \\
\hline Apostolic or Pentecostal & 14.0 & 13.4 & -4.9 \\
\hline Other & 70.2 & 97.7 & 39.1 \\
\hline No religion & 269.8 & 468.4 & 73.6 \\
\hline Not stated & 72.9 & 125.3 & 71.8 \\
\hline Total & $4,588.3$ & $4,761.9$ & 3.8 \\
\hline
\end{tabular}

In addition to the almost 4 million Christians, 63,443 Muslim and over 14,000 Hindus, other major world religions include Buddhism $(9,758)$ and Judaism $(2,557)$. Those who identify as having no religion number 468, 421 (an increase of $73 \%$ ) with Irish nationals making up $77 \%$ of these (73). This trend towards no-religion echoes international patterns in Western, once Christian-majority nations. In 28 of 35 countries studied across datasets in a recent analysis report, the actively religious are a minority of the 
adult population (PEW Research Center, 2019). Some impacts of this trend on adolescent wellbeing are discussed in a later section.

Of course it is important to note that 'no religion' does not denote atheist or agnostic. We cannot interpret further than nonidentification with a religious tradition. An RTE exit poll on the day of the last general election (McShane and Fanning, 2016) noted that $14 \%$ of the poll put themselves in the 'no religion' group. However, the RTE poll included some distinctions within this category: only $1 \%$ of the group said they were agnostic, with $4 \%$ atheist. $9 \%$ said that while they were 'not religious', they did consider themselves 'spiritual.'

\section{C) Digital Technology}

Third, concerns about the harmful effects of digital technology. The Canadian researchers describe how digital devices were initially welcomed in schools for their potential in independently accessing information, networking with experts and other schools, and supporting students with learning disabilities. Now, educators and mental health specialists often mention the anxieties that occur among adolescents because of cyber-bullying, especially among girls. 'They worry about short attention spans, digital distraction and lack of depth or focus resulting from excess screen time' (CODE, 2018, 13). Teachers are also increasingly concerned about the digital dis-inhibition in online interaction in the form of insults and rage, exceeding anything that might be said faceto-face.

\section{D) Targeted Violence}

The final international trend that has contributed to the educational emphasis on wellbeing is 'nations bound together by incidents of hate, exclusion and violence' (CODE, 2017, 6), where immigrant newcomers and other groups are harassed or bullied 
for their actual or imputed race, religion or sexual orientation. For example, between July 2016 and June 2017, there were 1,062 racist incidents and 938 incidents involving religious sectarianism reported to the Police Service of Northern Ireland (PSNI) (The Guardian, Nov 12, 2017). Some 98 racist incidents or those motivated because of someone's ethnic background or religion were recorded by Gardaí in the first six months of 2016 - a near doubling of the numbers logged for the previous year (The Irish Times, Oct 16, 2016). In the United Kingdom, a body of evidence is emerging to indicate that in a rapidly secularising culture, young people who engage in religious practice/hold religious beliefs can be undermined, stigmatised and feel left out or left behind (cf Moulin, 2017; Ipgrave 2012). This latter point forms part of a larger discussion on ill-being below.

According to the Ontarian team of researchers, these international tendencies have provoked a new age of education, one which takes seriously issues of identity and wellbeing, and links them to learning (CODE, 2018).

\section{The Age of Learning, Wellbeing and Identity}

This paradigm shift in education to encompass identity and wellbeing has implications for school curricula and communities. The Age of Learning, Wellbeing and Identity suggests identity as integral to all human development including achievement and wellbeing; students themselves highlight identities as central to well-being (CODE, 2018). But identity issues, including those of religious identity, are complex: young people can have many, sometimes conflicting, identities (cf Benson and Elder Jr, 2011). The CODE team asserts it is important they see themselves in the curriculum and community of their schools, and at the same time, reach out to and engage with the holders of other identities in service of a greater public good. Religious Education, 
provides 'a space like no other' to critically reflect on issues of dignity and identity, on questions of meaning and depth, and the responses of religious and non-religious worldviews (Sullivan, 2017). The 'space' of RE allows students to come to know something of themselves and each other and the wider world (NCCA, 2017b).

'RE offers a space like no other: for encounter, explanation, and empathy; for expression, interpretation, and imagination; for interrogation, questioning, and reflection. ... It gives an opportunity for students to experience and to bring into dialogue with one another both insider and outsider perspectives with regard to religious issues. It prompts pupils to think about similarities and differences between people and, in so doing, to reflect upon their own uniqueness and forms of belonging (Sullivan, 2017, 7).

The role of Religious Education and its potential to contribute to the wellbeing of young people is explored in the final section of this paper

\section{Religion and wellbeing}

The relationship between religion and health has a complicated history. In 1897, the sociologist Émile Durkheim posited that the suicide rate of a nation was largely dependent on the religious practices of its population. Protestants, for example, displayed greater emotional health issues than Catholics because Protestantism did not promote sufficient levels of social integration (in PEW, 2019, 25).

Ensuing decades brought the potentially harmful effects of religion to public attention, in part due to the popular writings of secular intellectuals. In his 1895 book The AntiChrist, Nietzsche famously described Christianity as a "sickness'. For Marx, religion was 'the opium of the people', while Freud compared religion to a childhood neurosis. Even later in the 20th century, some influential psychologists continued to 
follow Freud's lead by defining religion as a neurosis that should be cured by psychotherapy.

\section{The relationship between religion and wellbeing: assessing recent evidence}

As research on religion became increasingly influenced by scientific rigour, many studies found that religious people tend to live longer, get sick less often and are better able to cope with stress (PEW, 2019, 25). For instance, according to a comprehensive study undertaken in 2012 , religion is positively associated with life satisfaction, happiness and morale in 175 of 224 reports (78\%) (Koenig, King \& Carson). Of 100 studies referred to in The Handbook of Religion and Health, 79 demonstrate a positive correlation between religious involvement and wellbeing (Koenig, McCullough and Larson, 2002). Other studies have found either no clear association or a negative association (where religion is associated with worse health outcomes). For example, several studies have found that religious people tend to have a higher body mass index (BMI) (Koenig, King \& Carson, 2012). Whereas religiously active people tend to smoke and drink less, they are not healthier in terms of exercise frequency and rates of obesity (PEW, 2019, 5).

More recently, Religion and Well-being: Assessing the Evidence (Spencer et al, 2016), reveals a marked positive correlation between religion and wellbeing. This extensive summary study, which evaluates the evidence from 139 academic studies, systematises, categorises and analyses the complex, multivalent relationship between religion and wellbeing from over thirty years of academic literature. It also aims to clarify the relationship between religion and wellbeing by teasing apart the different ways 'religion' and 'wellbeing' have been understood in academic literature and surveys. Although not neatly categorised, with different studies sometimes spreading 
over different categories, it identifies five conceptions of religion and four of wellbeing as follows:

\section{Conceptions of religion}

- Social religious participation: the active (and regular) participation in group religious worship services, although some studies include other forms of religious social participation, such as volunteering.

- Religious personal participation: engaging in acts of private devotion such as prayer, scripture reading, or listening to religious music.

- Religious belief: personal belief in God or a higher power, and assent to tenets or doctrines of a religious group, for example, belief in an afterlife.

- Subjective religiosity: the degree of influence that beliefs have on a person's decisions and lifestyle and the sense of having a personally meaningful relationship with God or a higher power.

- Religious affiliation: the extent to which an individual identifies with religion.

\section{Conceptions of wellbeing}

- Mental health pertains to such measures as depression and anxiety; it has a more clinical focus than subjective wellbeing.

- Physical health pertains to indicators including chronic pain, recovery rate from illness, and mortality rate and like mental health is a more clinical category than subjective webeing.

- Health supporting behaviours pertains to those activities that tend to have a positive effect on physical health, such as by preventing substance abuse or addiction, or by encouraging exercise or healthy eating. (As there are 
significantly fewer studies in this area the summary study could not draw any strong conclusions on the measure of health supporting behaviours).

- Subjective wellbeing pertains to measures of self-reported happiness, including life satisfaction, personal evaluation of progress towards life goals, and having a sense of meaning in life (6-8).

Once identified, these conceptions of religion and wellbeing were then used as a framework for analysing the survey findings.

\section{Main empirical findings on the relationship between religion and wellbeing}

Overall, the data accrued show that religion is good for wellbeing, with certain aspects of religion better correlated with certain aspects of wellbeing. Generally, it appears that the more serious, genuinely held and practically-evidenced a religious commitment is, then the greater the positive impact it is likely to have on wellbeing (Spencer et al, 2016). These findings corroborate a 2019 Pew Research Center longitudinal study of the relationship between religion and wellbeing. The PEW analysis of survey data from 26 countries showed that people who are active in religious congregations tend to be happier and more civically engaged than either religiously unaffiliated adults or inactive members of religious groups. The study found that regular participation in a religious community is clearly linked with higher levels of happiness and civic engagement (specifically, voting in elections and joining community groups or other voluntary organizations). Moreover, societies with declining levels of religious engagement could be at risk of declines in personal and societal wellbeing.

Using the categories identified by Spencer et al, the findings of these two international longitudinal studies can be summarised as follows: Social participation has 
the strongest positive correlation across all dimensions of wellbeing. The strong consensus among the studies analysed was that this type of religious participation was conducive to all signals of wellbeing. 'Regular, frequent religious service attendance seemed to have the biggest impact on well-being, though lower levels of attendance and other types of participation, such as volunteering, also has some effect' (Spencer et al, 2016, 13). Religious personal participation (more private engagement) also shows a strong positive correlation. In short, both recent international longitudinal studies indicate that participation, whether social or private, demonstrates a strong positive correlation with wellbeing, most notably in the area of mental health. This echoes findings from the Irish context: in Well-Being and Post-Primary Schooling: A review of the literature and research, O'Brien (2008) identifies a strong positive correlation between religious involvement and wellbeing.

Religious belief has a largely positive, but more varied, impact on the different measures of wellbeing. Spencer et al found a strong positive correlation with subjective wellbeing; this is less pronounced in relation to mental health. Significantly weaker correlations were found with physical health and health supporting behaviours. So despite what Joan of Arc might say, belief matters but it is not everything! Types of belief are also important. For instance, belief in a punitive God can have different effects to belief in a God who is benevolent. This corroborates the PEW study which suggests that people who view humans as sinful and participate in religious communities that emphasise human sinfulness are more likely to suffer from anxiety and depression (PEW, 2019).

Religious affiliation appears to have the weakest effect on wellbeing. It is not that the evidence suggests negative effects of religious affiliation, but it does not imply a strong positive correlation either (Spencer et al, 2016). In the same vein, the PEW 
study found comparatively little evidence that religious affiliation, by itself, is associated with a greater likelihood of personal happiness or civic involvement (2019).

Although the surveys did not focus on any particular age group, a number of the individual studies analysed concentrated on the effects of religion on young people of Junior Cycle age. For example, Ball, Armistead, and Austin (2003) surveyed 492 African-American females aged 12 to 19 living in urban environments. They found that greater religiosity, specifically belief, affiliation and social participation, was correlated with greater self-esteem and psychological functioning.

\section{Some notes of caution}

While different aspects of religion correlate with different dimensions of wellbeing, correlation is not causation (Spencer et al, 2016, 17). It cannot be guaranteed, for instance, that participation in religious services will improve one's mental health. Although social religious participation seems to be the most strongly correlated with wellbeing, there is some evidence that group participation for extrinsic rather than intrinsic reasons - seeing participation as a means to another end (for example, recognition or advancement) rather than an end in itself - can eradicate the positive benefits of such participation. It can even be associated with negative benefits. In other words, religiosity needs to be authentic.

As soon as the desire to achieve well-being becomes the goal of religiosity, rather than a side-effect, the whole system collapses in on itself. To join community for the sake of 'me' is to kill community. To be generous for the sake of receiving something is to obliterate the meaning of generosity. Prayer that is a shopping list directed at some cosmic cash card soon ceases to be prayer (Spencer et al, 2016, 17). 
Second, none of it proves that 'religion' is true. The surveys covered in these reports cover a range of different religions, which differ in terms of both belief and practice. What the collective findings do suggest is that religiosity is a complex phenomenon, deeply connected and generally (but not always) positively correlated with human wellbeing.

Third, many factors impinge on wellbeing and the relationship between these is also complex. For instance, in their work in determining personal wellbeing in the Muslim culture of Pakistan, Suhail and Chaudhry (2004) found that work satisfaction, social support, social class, income level and marital status as well as religious affiliation were all good predictors of subjective wellbeing.

A final note of caution pertains to the implications for Religious Education: to lift up religiosity as a well from whence wellbeing can be drawn is not to endorse a situation where any religion or form of Religious Education is foisted on students or their families.

\section{The other side of wellbeing and identity}

No discussion of wellbeing and religion would be complete without consideration of what we might term illbeing. If wellbeing is understood as 'present when students realise their abilities, take care of their physical wellbeing, can cope with the normal stresses of life, and have a sense of purpose and belonging to a wider community' (NCCA, 2017a, 17), then illbeing can be construed as the absence of these. In the new age of education described by the CODE researchers, learning, wellbeing and identity are inextricably linked. Religious identity is a function of human identity; accepted or undermined, it can contribute to wellbeing/illbeing respectively. 
A 2018 study on religious affiliation found that 16 to 29 year-olds in Ireland selfidentified as follows:

- $58 \%$ Christians (54\% Catholic, $2 \%$ Protestant, $2 \%$ other Christian),

- $1 \%$ Muslims,

- $3 \%$ of other religions,

- $39 \%$ not religious (Bullivant, 2018, 6).

$26 \%$ of young people in this age group say they never attend a religious service (7). A study by Heinz et al (2018) also found low levels of religious practice and religiosity among young people in Ireland. Since at least the beginning of this millennium, adolescents in England who regularly attend and participate in religious activities are minority among their peers (Kay and Francis, 2001). Researchers such as Ipgrave (2012) and Moulin (2016) have identified adverse consequences for young people who practice: adolescents who do not have religious commitments can consider religious participation as 'abnormal'. In these settings, religious adolescents risk ridicule and social exclusion (Ipgrave, 2012, 265). Similarly, the international research project REDCo (Religion in Education. A Contribution to Dialogue or a Factor of Conflict in Transforming Societies of European Countries) undertaken with 14-16 year olds found that some religiously-committed students feel vulnerable in the classroom (Weisse, 2011). The experiences of those from a traditionally majority position which goes into rapid decline are a subject of some concern internationally (Moulin 2016, Ipgrave 2012, Rymarz and Graham, 2006). Ipgrave (2012) concludes that when students feel forced to conceal or deny their religious identity, both personal and communal (school community) wellbeing are compromised.

If, as an earlier section has demonstrated, religion is a proven source of wellbeing, then Religious Education as the critical encounter between education and 
religion warrants exploration to benefit the school community and to help fulfil the wellbeing requirements of the Framework. And so we move to the role Religious Education can play in a programme where the focus is the holistic wellbeing of the child.

\section{Religious Education, wellbeing and the new Junior Cycle}

Religious Education (RE) across Europe is the subject of much debate.

However, whereas the role and appropriateness of different approaches to Religious Education is contested, the vast majority of European countries accept the necessity of Religious Education in schools (Schreiner, 2013). For instance, Ofsted, the inspectorate for England and Wales, considers Religious Education, at its best, to be intellectually challenging and personally enriching. It helps young people develop beliefs and values, and promotes respect and empathy, which are important in our diverse society. It fosters civilised debate and reasoned argument, and helps students to understand the place of religion and belief in the modern world (Ofsted, 2013).

Three approaches to Religious Education occur, shaped by national and regional contexts:

$\circ$ Teaching organised in collaboration between state and religious communities (denominational/confessional/non-confessional)

- Teaching organised exclusively by state authorities (non-confessional, religious studies)

- Teaching organised by religious communities that have exclusive responsibility for RE (denominational/confessional/catechetical) (Schreiner, 2013). 
Up until the Education Act of 1998 (see below), the latter was the predominant approach to post-primary Religious Education in Ireland. The Department of Education and Skills refers to this approach as 'religious instruction' (DES, 2018b).

Over the last two decades, in light of increasing social, cultural and religious tensions in many European countries, the Council of Europe has increasingly looked to $\mathrm{RE}$ as a means of promoting intercultural understanding and respect for diverse beliefs. In 2005 the Parliamentary Assembly of the Council of Europe recommended 'a good general knowledge of religions and the resulting sense of tolerance are essential to the exercise of democratic citizenship' (cited in NCCA, 2017b, 28)). The Council also called on Governments to

do more to guarantee freedom of conscience and religious expression, to encourage religious instruction, to promote dialogue with and between religions, and to further the cultural and social expression of religions (cited in NCCA, 2017b, 28)

More recently the Council's recommendations go beyond just teaching about religion; they promote the development of attitudes such as sensitivity and respect for religious and non-religious traditions, as well as competences such as religious literacy and understanding. Such competences, the Council holds, are necessary for intercultural living, and Religious Education has an important contribution to make in this regard.

Findings from a number of research projects across Europe agree that students and teachers value Religious Education as it:

- facilitates respectful dialogue in the classroom

○ creates 'safe spaces' for dialogue

$\circ$ engages with competing claims to truth 
$\bigcirc$ helps young people analyse media representations of religions.

Research findings also show that young people value the place of RE and want a safe space to learn and talk about their own and others' religions, beliefs and truth claims in schools (NCCA, 2017b).

\section{Post-primary Religious Education (Junior Cycle) in Ireland}

The Irish State is committed to ensure that 'all students, in accordance with their abilities' should have 'formative experiences in moral, religious and spiritual education' (Government of Ireland, 1992, 50) while maintaining due regard for the rights of children and their parents to freedom of religion. In this context, it is important that post-primary Religious Education (RE) in Ireland is understood independently of RE at primary level. In the latter case, RE comes under the sole remit of the school patron. It has been acknowledged by patrons, the State, parent bodies and other groups that the traditional model of church patronage, still very dominant in Ireland, is in need of reform (cf O'Connell, 2018). However, the landscape of post-primary patronage is quite different. In broad terms, patronage of post-primary schools falls into 3 sectors:

○ Voluntary secondary schools, usually denominational but also including groups such as Educate Together

- Schools and community colleges managed on behalf of the state by local Educational and Training Boards (ETBs), formerly VECs

○ Community and comprehensive schools, usually resulting from an amalgamation of schools. In these cases, the state and another body (usually a religious congregation or local bishop who had been patron of an amalgamating school) act as co-patrons. 
The Education Act of 1998 marked a new departure for Irish education and for postprimary RE. Up to that point, education was underpinned by the Intermediate Education (Ireland) Act 1878, an act of the British Parliament. One significant effect of the Education Act (1998) was the removal of Section 5 of the 1878 Act which effectively prohibited State involvement in the oversight and examination of RE. Change, which had been bubbling in the background, was almost immediate (Byrne, 2018).

\section{The Junior Certificate Religious Education Syllabus (2000)}

The year 2000 saw the introduction of the Junior Certificate Religious Education Syllabus (JCRES), with students taking the first State-certified Junior Certificate RE examination in June 2003. Developed by the National Council of Curriculum and Assessment (NCCA) on behalf of the State, the JCRES encourages students to reflect

on human experience and to understand and interpret that experience. A significant aim, among others, is to foster an appreciation of 'the richness of religious traditions and to acknowledge the non-religious interpretation of life' (Department of Education and Science, 2000, 5). It also offers opportunities to 'develop an informed and critical understanding of the Christian tradition' (4). At the time the JCRES was introduced, the Irish Catholic bishops offered guidelines for how the syllabus might be used in Catholic schools and for the faith formation of Catholic students (Irish Catholic Bishops' Conference, 1999). This more confessional approach to RE has not been the expressed position in State managed post-primary schools since the introduction of the JCRES in 2000, although in some instances practice may suggest otherwise (DES, 2018b).

The specification for Junior Cycle Religious Education (2019) 
The new specification for Junior Cycle Religious Education (NCCA, 2019) is due to be implemented in schools in September 2019. Thus RE continues as a statecertified subject, in line with the approach of the Framework for Junior Cycle (2015). Like its predecessor the JCRES, this specification is intended for all students, whatever their religious faith or worldview. It is intended to ensure that students are exposed to a broad range of religious traditions and to the non-religious interpretation of life. It does not 'provide religious instruction in any particular religious or faith tradition' (DES, 2018b, 2).

Recent Circular Letters from the Department of Education and Skills (DES) have attempted to clarify the approach to RE in community and ETB post-primary schools. The Department does not require any school to include Religious Education at Junior Cycle as a mandatory subject. Accordingly, schools 'have discretion to determine if they provide the subject at all or if it is to be mandatory or optional in any particular class group or year' (DES, 2018b, 2). Further, the more formative/confessional approach to $\mathrm{RE}$ as a subject which may have existed in some State-managed schools is explicitly dealt with. Where 'religious instruction and worship in accordance with the rites and practices of a particular denomination' (DES, $2018 b, 3)$ is offered in ETB or community schools and colleges:

- It must not be associated in any degree with the NCCA developed syllabus/specification

- It must not be provided in timetabled class periods

- A newly required opt-in by parents for their children is required (DES, 2018b).

\section{Religious Education as a Junior Cycle subject}


The Framework for Junior Cycle identifies:

- 8 principles of education, one of which is wellbeing;

- 8 key skills that underpin successful learning;

- 24 statements of learning (SOLs) describing what students should know, understand, value and be able to do at the end of their time in Junior Cycle (NCCA, 2015).

The Junior Cycle curriculum that a school provides must honour the 8 principles, meet all 24 statements of learning, and cultivate the 8 key skills in a way that honours its characteristic spirit and meets the learning needs and interests of its students (DES, 2016). This implies lots of flexibility for individual schools. For many, RE has a significant role to play in the provision of such a curriculum. The Religion Teachers' Association of Ireland (RTAI, 2017) has shown how RE fosters all 8 key skills (see Appendix A for examples of how RE can foster elements of the 8 key skills). The teachers go on to contend that 'it is hard to see how some of the twenty-four statements of learning identified in the Framework, can be achieved without appropriate time being given to Religious Education'. Of the six SOLs which relate specifically to wellbeing (NCCA, 2017a, 22), three directly link to RE (NCCA, 2019, 8):

- The student has an awareness of personal values and an understanding of the process of moral decision making (SOL 5)

- The student values what it means to be an active citizen, with rights and responsibilities in local and wider contexts (SOL 7)

- The student takes action to safeguard and promote her/his wellbeing and that of others (SOL 11). 
Where it is offered by a school as a subject in the new Junior Cycle, Religious Education follows the approach and requirements of the Framework, consistent across all subjects. Therefore Religious Education as a subject is

- timetabled for a minimum of 200 hours of student engagement

- designed to be as universal as possible, providing meaningful and valuable learning opportunities for students from all cultural backgrounds and individual circumstances.

- accessible as possible to students with Special Educational Needs (SENs).

At the same time, the vision and flexibility of the Framework permits a Junior Cycle where for some schools, Religious Education will be more than a subject; RE learning and activities may form part of Other Learning Experiences. According to the Guidelines, elements of wellbeing learning or activities could take place in Religious Education, including once-off events, such as school retreats (NCCA, 2017, 50).

\section{Religious Education: the potential to contribute to Junior Cycle Wellbeing}

The Junior Cycle Religious Education Specification (NCCA, 2019) presents a rationale for Religious Education that resonates with the core questions of learning, wellbeing and identity outlined earlier. It sees RE as integral to any programme that promotes the holistic development of the person because it facilitates the intellectual, social, emotional, spiritual and moral development of students. In an open letter to the Minister for Education and Skills, the Religion Teachers' Association of Ireland (RTAI, 2018) employs the expertise and experience of its members to set out its view and vision of Junior Cycle Religious Education. Taken together, these documents articulate four ways in which RE can contribute to the promise of holistic education in the Education Act 
(1998) and the hope for wellbeing as a principle and curricular area in the new Junior Cycle.

\section{1) Exploring deep questions}

Religious Education allows students to engage with deep questions relating to meaning and purpose, life and relationships (Meehan, 2018). 'It helps students to reflect, question, interpret, encounter, imagine and find insight for their lives. The students' own experience and continuing search for meaning is encouraged and supported' (NCCA, 2019, 4). The Background Paper and Brieffor the Review of Junior Cycle Religious Education (NCCA, 2017b), echoing the experience of RE teachers (RTAI, 2018), describes how RE provides 'a space like no other' for students to discuss questions of depth and meaning and to come to know themselves and each other. Here is exactly the kind of space needed to address the questions thrown up by the Age of Learning, Wellbeing and Identity (CODE, 2018).

\section{2) Engaging with a variety of belief systems}

Religious Education provides opportunities for students to encounter and engage with the variety of religious beliefs and other interpretations of life, found in Ireland and elsewhere. It encourages respect and understanding of different beliefs, perspectives and ways of living, including the non-religious response to human experience. This is important in light of the international trends of changing demographics and 'targeted violence', and the recommendations that students need to understand and advocate 'for those who are different from us, as well as for those who are the same' (CODE, 2018, 136). Religious Education promotes personal reflection, ecumenical engagement, interreligious and intercultural dialogue, and ecological education. In this way, RE promotes social cohesion, affording students the opportunity to engage with traditions 
and worldviews apart from their own, allowing them to develop the skills and attitudes they need to engage positively, respectfully and constructively in a pluralist society (NCCA, 2019).

\section{3) Religion, history and society}

In every culture, religion and history have always been intertwined. Religious Education develops students' historical consciousness and gives them a framework for understanding the past and present within their contexts. It helps them to understand religions as dynamic, internally diverse and evolving over time. Religious Education within an Irish context offers students an opportunity to develop an understanding of how different religions have contributed to the society in which we live. Finally, RE as part of a state curriculum is grounded in values of freedom, dignity, inclusion, justice and equality. As such it can contribute to building a more socially cohesive society (NCCA, 2017b).

\section{4) Religious Education and moral development}

In Religious Education, students are encouraged to engage critically with a variety of moral codes as part of religious traditions, and principles of moral behaviour, to help them reach a thoughtful ethical stance that will serve as a foundation for decisions in their lives (NCCA, 2019). The RTAI (2018) describes how Religious Education has developed in such a way that it can be open to all participants, contributing to their spiritual and moral development, whatever their belief system.

In these four ways, RE can contribute to the vision of education articulated in the Education Act (1998) and the hope for wellbeing of the new Junior Cycle.

\section{Conclusion}


With wellbeing at the core of the new Junior Cycle, it is timely to explore all its potential sources. The empirical evidence outlined in this paper demonstrates that religion can be one of those sources. The paper also outlines how Religious Education, with sound content and pedagogy that accurately and respectfully represents religions, can contribute to the wellbeing of young people and of society. Both the Framework for Junior Cycle (2015) and Junior Cycle Wellbeing Guidelines (2017) make room for this.

One does not have to identify or belong to any faith tradition in order to engage with religion or explore its connections with moral development, history and society, interreligious/non-religious understandings and the search for meaning and purpose. Ysra Daley-Ward - part of a new generation of writers and poets, born in Britain to Nigerian and Jamaican parents, captures this well:

\title{
to the elders
}

\author{
I cannot find the God you serve \\ and I have been known to stay out all \\ night, searching.
}

(Daley Ward, 2017, 6)

Seeking and searching is part of the human condition. Religion can help in that quest. Both international longitudinal studies examined in this paper indicate that the correlation between religion and wellbeing is generally strong, in some cases very strong (PEW, 2019; Spencer et al, 2016). Good Religious Education is a well from which we can draw. It is a well that can help sustain young people of today in this age of identity, learning and wellbeing. 


\section{References}

Ball, Joanna, Lisa P. Armistead, and BJ Austin. 2003. "The relationship between religiosity and adjustment among African-American, female, urban adolescents", Journal of Adolescence. 26(4): 431-46.

Benson, Janel. E., and Glen H. Elder Jr. 2011. "Young adult identities and their pathways: A developmental and life course model", Developmental Psychology, 47(6): 1646-1657. http://dx.doi.org/10.1037/a0023833

Bullivant, Steven. 2018. Europe's Young Adults and Religion: Findings from the European Social Survey (2014-16) to inform the 2018 Synod of Bishops. London: Benedict XVI Centre for Religion and Society, St Mary's University's, London and the Institut Catholique de Paris.

Byrne, Gareth. 2019. "Religion and education: A changing and challenging relationship." In Ireland's Yearbook of Education 2018/2019, edited by Brian Mooney. Dublin: Education Matters, 34-40.

Campbell, Carol, Ken Zeichner, Ann Lieberman, Ann, and Pamela Osmond-Johnson. 2017. Empowered educators in Canada: How high-performing systems shape teaching quality. Marblehead, MA: John Wiley \& Sons.

Casson, Ann, Trevor Cooling, and Leslie J. Francis. 2017. Lessons in Spiritual Development: Learning from Leading Christian-ethos Secondary Schools. London: Church House Publishing.

Central Statistics Office. 2017. Census 2016 Summary Results - Part 1. Dublin: Central Statistics Office, Ireland.

https://www.cso.ie/en/media/csoie/newsevents/documents/census2016summaryresultsp art1/Census2016SummaryPart1.pdf

Council of Ontario Directors of Education (CODE). 2018. Leading from the Middle: Spreading Learning, Well-being, and Identity Across Ontario. Ontario: CODE Consortium.

Daley-Ward, Ysra. 2017. bone. New York: Penguin.

Department of Education and Science (DES). 2000. Junior Certificate Religious Education Syllabus. Dublin: Department of Education and Science https://www.curriculumonline.ie/getmedia/c0c1f394-79c8-4455-bea5c9e014a9945d/JCSEC22_religion_syllabus.pdf

Department of Education and Skills (DES). 2015. Framework for Junior Cycle. Dublin: Department of Education and Skills https://www.education.ie/en/Publications/Policy-Reports/Framework-for-Junior-Cycle2015.pdf

Department of Education and Skills (DES). 2016. Circular Letter 0024/2016. Dublin: Department of Education and Skills https://www.education.ie/en/Circulars-andForms/Archived-Circulars/c10024_2016.pdf

Department of Education and Skills (DES). 2018a. Wellbeing Policy Statement and Framework for Practice 2018-2023 
https://www.education.ie/en/Publications/Policy-Reports/wellbeing-policy-statementand-framework-for-practice-2018\%E2\%80\%932023.pdf

Department of Education and Skills (DES). 2018b. Circular Letter 0062/2018. Dublin: Department of Education and Skills https://www.education.ie/en/Circulars-and-

Forms/Active-Circulars/c10062_2018.pdf

Dooley, Barbara A., and Amanda Fitzgerald. 2012. My World Survey: National Study of Youth Mental Health in Ireland. Dublin: Headstrong: The National Centre for Youth Mental Health and UCD School of Psychology.

http://www.ucd.ie/t4cms/MyWorldSurvey.pdf

Francis, Leslie. J., Gilpin, G., and Robbins, M. 2000. "Religion and happiness: a study in empirical theology." Transpersonal Psychology Review, 4(2): 17-22.

Government of Ireland. 1992. Charting our Education Future: White Paper on Education. Dublin: The Stationery Office.

Government of Ireland, Education Act, 1998, Section 9 (d). http://www.irishstatutebook.ie/eli/1998/act/51/section/9/enacted/en/html

Heinz, Manuela, Kevin Davison, and Elaine Keane. 2018. "'I will do it but religion is a very personal thing': teacher education applicants' attitudes towards teaching religion in Ireland", European Journal of Teacher Education, 41 (2): 232-245, DOI: 10.1080/02619768.2018.1426566

Ipgrave, Julia. 2012. "Relationships between local patterns of religious practice and young people's attitudes to the religiosity of their peers", Journal of Beliefs \& Values, 33 (3): 261-274, DOI: 10.1080/13617672.2012.732805

Irish Catholic Bishops' Conference. 1999. Guidelines for the Faith Formation and Development of Catholic Students: Junior Certificate Religious Education Syllabus. Dublin: Veritas

Kay, William, and Leslie Francis. 2001. "Religious Education and School Assembly in England and Wales: What do Religious Minorities Think?" In Towards Religious Competence: Diversity as a Challenge for Education in Europe, edited by Hans-Günter Heimbrock, Christoph T. Scheilke, and Peter Schreiner, 117-128. Münster: LIT-Verlag.

Koenig, Harold G., Michael E. McCullough, and David B. Larson. 2001. Handbook of Religion and Health. New York: Oxford University Press.

Koenig, Harold G., Dana E. King, and Verna Benner Carson. 2012. Handbook of Religion and Health, Second Edition. New York: Oxford University Press.

McDonald, Henry. 2017. "Racially motivated crimes now exceed sectarian ones in Northern Ireland." The Guardian, November 12. https://www.theguardian.com/uknews/2017/nov/12/racially-motivated-crimes-now-exceed-sectarian-ones-in-northernireland.

McShane, Ian, and Martha Fanning. 2016. "RTÉ/Behaviour \& Attitudes 2016 General Election Exit Poll Report”. RTE, February 26.

Meehan, Amalee. 2018. "The Sickness of Long Thinking: Religious Education and the New Junior Cycle." In Contemporary Perspectives on Catholic Education, edited by John Lydon. England: Gracewing, 59-67. 
Mental Health Ireland. 2018. "Life Stages, Teens.” Accessed 17 July 2018. http://www.mentalhealthireland.ie/teens/

Moulin, Daniel. 2016. "Reported Experiences of Anti-Christian Prejudice among Christian Adolescents in England”, Journal of Contemporary Religion, 31 (2): 223-238. DOI: $10.1080 / 13537903.2016 .1152679$

National Council for Curriculum and Assessment (NCCA). 2017a. Guidelines for Wellbeing in Junior Cycle. Dublin: NCCA

National Council for Curriculum and Assessment (NCCA). 2017b. Background Paper and Brieffor the Review of Junior Cycle Religious Education. Dublin: NCCA.

National Council for Curriculum and Assessment (NCCA). 2019. Junior Cycle Religious Education. Dublin: NCCA. https://curriculumonline.ie/getmedia/7dd9dc719adb-4cf2-aa36-a5200c4f68be/Religious-Education.pdf

O'Brien, M. 2008. Well-Being and Post-Primary Schooling: A Review of the Literature and Research. Dublin: NCCA

https://www.ncca.ie/media/2491/wellbeing_and_postprimary_schooling_a_review_of_t he_literature_and_research.pdf

O'Brien, Maeve and Andrew O'Shea. 2017. A Human Development (PSP) Framework: For Orienting Education and Schools in the Space of Wellbeing. Dublin: NCCA https://www.ncca.ie/media/2488/a-human-development-framework-psp.pdf

O'Connell, Dan. 2018. "Catholic Primary Schools - on Rapidly Thinning Ice”, The Furrow 69 (12): 660-671.

The Office for Standards in Education, Children's Services and Skills (Ofsted). 2013. Religious education: realising the potential. Manchester: Ofsted

Parkin, Andrew. 2015. International report card on public education: Key facts on Canadian achievement and equity. Ottawa, ON: The Environics Institute. Accesses 17 July 2018. Retrieved from: https://www.environicsinstitute. org/projects/projectdetails/international- report-card-on-public-education-key-facts- on-canadianachievement-and-equity.

Parliamentary Assembly of the Council of Europe, Recommendation 1720 (2005) on education and religion.

PEW Research Center. 2019. Religion's Relationship to Happiness, Civic Engagement and Health Around the World http://www.pewforum.org/wpcontent/uploads/sites/7/2019/01/Wellbeing-report-1-25-19-FULL-REPORT-FORWEB.pdf

Religion Teachers Association of Ireland (RTAI). 22 February 2018. Letter to Minister for Education and Skills on Circular 0013/2018.

Rymarz, Richard, and John Graham. 2006. "Australian Core Catholic Youth, Catholic Schools and Religious Education”, British Journal of Religious Education 28: 79-89.

Schreiner, Peter. 2013. "Religious Education in a European Context", Hungarian Educational Research Journal, 5-15. 
Schneiders, Sandra. 2000. "Religion and Spirituality: Strangers, Rivals or Partners?" The Santa Clara Lectures 6, no. 2.

Spencer, Nick, Gillian Madden, Clare Purtill and Joseph Ewing. 2016. Religion and Well-being: Assessing the Evidence. London: Theos.

Suhail, Kausar, and Haroon Rashid Chaudhry. 2004. "Predictors of Subjective WellBeing in an Eastern Muslim Culture." Journal of Social and Clinical Psychology 23 (3): 359-376.

Sullivan, John. 2017. “A space like no other.” In Does Religious Education Matter?, edited by Mary Shanahan. London: Routledge.

Weare, Katherine. 2015. What Works in Promoting Social and Emotional Well-being and Responding to Mental Health Problems in Schools? Advice for Schools and Framework Document. London: National Children's Bureau (NCB).

Weisse, Wolfram. 2011. "Reflections on the REDCo Project." British Journal of Religious Education, 33 (2): 111-125. The international research project REDCo (Religion in Education. A Contribution to Dialogue or a Factor of Conflict in Transforming Societies of European Countries) addressed the question of how religions and values contribute to dialogue or tension in Europe. 


\section{Appendix A}

Examples of how Religious Education can foster sample elements of each of the 8 key skills

\begin{tabular}{|c|c|c|}
\hline Key Skill & Key Skill Element & Student Learning Activity \\
\hline Being Creative & Imagining & Meditation/Mindfulness \\
\hline Being Literate & $\begin{array}{l}\text { Developing my spoken } \\
\text { language }\end{array}$ & $\begin{array}{l}\text { Recognising terms associated with } \\
\text { the key feasts/celebrations of major } \\
\text { world religions }\end{array}$ \\
\hline Being Numerate & $\begin{array}{l}\text { Seeing patterns, trends } \\
\text { and relationships }\end{array}$ & $\begin{array}{l}\text { Biblical patterns eg chapter and } \\
\text { verse; synoptic Gospel patterns }\end{array}$ \\
\hline Communicating & $\begin{array}{l}\text { Performing \& } \\
\text { presenting }\end{array}$ & Role Play as a methodology in RE \\
\hline $\begin{array}{l}\text { Managing } \\
\text { Information and } \\
\text { Thinking }\end{array}$ & Being curious & $\begin{array}{l}\text { Investigating different religious } \\
\text { beliefs and practices }\end{array}$ \\
\hline Managing Myself & $\begin{array}{l}\text { Making considered } \\
\text { decisions }\end{array}$ & $\begin{array}{l}\text { Considering moral codes of major } \\
\text { world religions }\end{array}$ \\
\hline Staying Well & Being spiritual & $\begin{array}{l}\text { Engaging with the spiritual } \\
\text { practices associated with religions }\end{array}$ \\
\hline $\begin{array}{l}\text { Working With } \\
\text { Others }\end{array}$ & Respecting difference & $\begin{array}{l}\text { Appreciating the differences and } \\
\text { similarities between people of } \\
\text { religious/non-religious worldviews }\end{array}$ \\
\hline
\end{tabular}


